\title{
A Single Currency For The GCC: Launching A New Culture
}

\author{
Saif S. Alsowaidi, (E-mail: s.alsowaidi@qu.edu.qa), Qatar University, Qatar
}

\begin{abstract}
The member states of the Gulf Cooperation Council (GCC) are moving towards launching a single currency by January 2010, an advanced step towards monetary union. These countries are characterized with a great degree of similarities whether political, economic, or social. This provides an advantage many regional economic groups lack. A single currency setting, as advocated in the literature, requires fulfillment of many conditions and requirements to assert its feasibility, desirability and durability. The SWOT methodology utilized in this paper presents a list of activities that must be thought of carefully before and after the year 2010, when the single currency is planned to circulate. Time is approaching fast, thus, GCC states should take serious steps in the remaining few years. The paper identifies very important issues that must be investigated and settled ahead of launching the common currency; among them the urgent need to establish super-national institutions and pooling legislations and economic environment.
\end{abstract}

\section{INTRODUCTION}

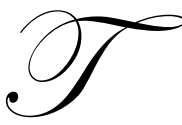

he Gulf Cooperation Council (GCC) was formed in 1980 by six states: Bahrain, Kuwait, Oman, Qatar, Saudi Arabia, and United Arab Emirates. An economic agreement was signed in the same year to advocate economic cooperation and integration; however, little has been accomplished per the scope of this agreement. It is only lately serious steps have been taken to pave the way towards the year 2010, where a single currency is to replace national currencies. If that is to happen, it will be the first form of currency arrangements among Arab countries in recent history. The single currency commitment was an outcome of several meetings of heads of these states, notably the meeting in Muscat in 2001, where all states agreed to peg their currencies to the US dollar by the end of 2002. Moreover, they agreed to select a set of economic convergence criteria that have to be satisfied by 2010 .

The targeted date of 2010 is viewed as a very ambitious goal given the time it took other currency areas to issue a single currency. For example, the Euro was an outcome of at least twenty-five years of coordination, planning, organization and political commitment among the member states of the European Union. While, one may argue that the number of the members of the GCC is much smaller than the currency area of the Euro and they are in a better position to learn from an existing European experience. Nevertheless, it took Europe, with its democratic institutions, many years to develop and empower, independent, and super-national institutions that, currently, govern the union. These institutions have played three outstanding roles. First, they have created a new center of evolving power of legislation and governance with different agenda than their counterparts in any member state of the union. Second, they have initiated an alternative body of policy design machine focusing on "super-national" objectives. Third, they are looked upon as the "non-aligned" institutions that are the "care-takers" of the Union, designing and implementing policies targeting the general welfare of member states. This third point is very important because many political and economic forms of cooperation among countries usually lacking such institutions, and thus deemed to be ineffective. These institutions constituted an essential part of its "sponsorship" team when the union was just a project. Nowadays, they are considered part of the union structure with strong and effective authorities and manifest; they are the governance body of the union. 
In all cases, economic unions must have a mechanism that is capable of initiating and inducing enough steam to keep the momentum at suitable speed. One must find this momentum in leadership that strongly believes in the union, its mission, values and objectives; and stresses this belief at all occasions. Many projects remain dreams as a consequence of the disarrayed belief of new leaders once the initiators leave the scene. It is therefore crucial to have the right leadership if the objectives are to be fulfilled. This has been the experience of the European Union; however, not all economic agreements have met the same destiny. Member states of the GCC realize that it takes more than desires and wishful thinking to launch a successful single currency. Extremely, good, reasonable and timed plans provide necessary, but not sufficient, conditions to have successful landing in 2010. Political commitment is the most important prerequisite to circulate, accept and honor a single currency. Such commitment in non-democratically elected governments is an issue that is to be pioneered, and, in the case of the GCC, will be tested in the coming years (European Central Bank, 2005).

Since the GCC states have already committed themselves to launch the single currency by 2010; at this stage, it becomes less relevant to assess whether that was a good decision. Moreover, the pre-qualification conditions to be a member of the new single currency area are not applicable to the six states, because they formed an area to which they belong at an ad hoc basis. In the future, certain conditions may apply to new joiners so that to assess and condition their eligibility to be members.

This paper adopts an alternative approach to examine the single currency among the GCC states. It adopts the approach of SWOT (strengths, weaknesses, opportunities, and threats) methodology, a widely known approach in strategic planning and management of change literature. One may argue that applying this technique helps in preparing a list of factors where they would be classified as points of strength that require enhancement; points of weakness that must be tackled; whereas identifying opportunities to be grasped and optimized; and threats that require further serious attention. Extensive analysis of the economies of the GCC states and the application of the methodology of optimum currency area may be found in studies by the Arab Planning Institute (2002), International Monetary Fund (2003), and European Central Bank (2005), among others. The rest of the paper is as follows. Section I presents the methodology of project management. Section II briefly discusses the SWOT methodology. Section III portrays the current status of the economies of the region; while Section IV presents the results of the SWOT analysis, where important internal factors are classified providing decision makers with a micro perspective towards the single currency. The conclusion is in the last section.

\section{PROJECT MANAGEMENT METHODOLOGY}

The single currency among the GCC states is looked at in this paper as a project. Like any project, it requires planning, organization, implementation, and assessment and following up. This cycle is depicted in Figure (1).

Figure (1): Project Management Cycle
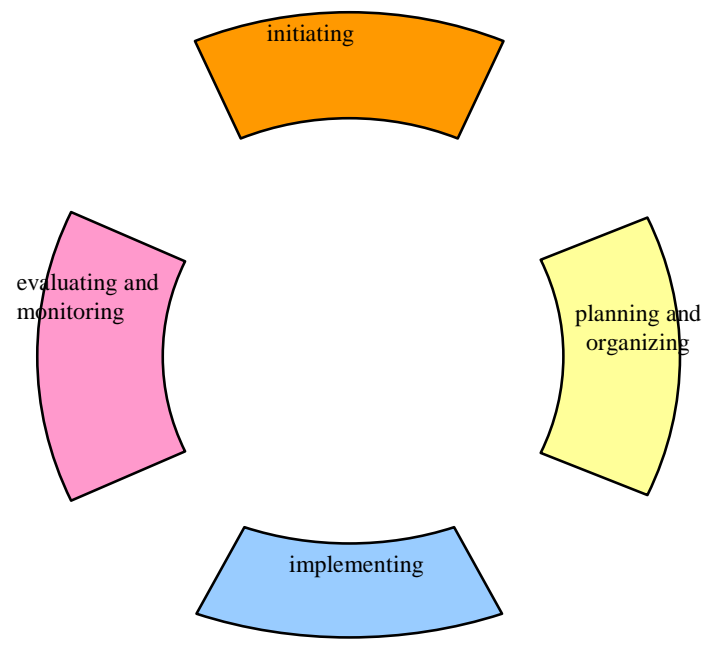
Initiating the project is the phase in which its objectives and scope are identified based on an analysis of the current situation. During this phase, project assumptions would be asserted as both points of strength and weaknesses are clearly recognized leading to a comprehensive analysis of stakeholders so that to understand their roles, expectations and needs. It is very important to develop a vision of what the organization likes to attain before the alternative tools and mechanisms are discussed and one (or may be more) is selected. At this stage, alternative options and choices of mechanisms that will change or modify the current business environment would be discussed and evaluated in terms of suitability to the objectives, requirements, cost, time, potential outcome, and ability of the management to maintain. A crucial element of success, which, in some cases, is over seen, is the "buy in" of various stakeholders who constitute the engine of change. This requires many talents on the side of the project preachers. The list includes political, psychological and empowerment techniques where they would be exposed to the importance of change and its impact on them. This requires good leaders of change, i.e., project management, with strong communication and leadership skills. Once the feasibility of the project is proven, a project charter would be prepared and approved by the highest authority in the business organization demonstrating commitment and endorsement.

The second stage is the planning or organization phase of the project where action plans will be prepared outlining the roles of each participant in the change. Participants may be required to work individually or in teams or a combination of both. In addition other logistic requirements are identified and are being prepared paving the way towards the implementation stage. Moreover, required governing policies, procedures, roles and responsibilities must be reviewed and endorsed before moving to the third stage. Right after completing these activities, a "kick-off" meeting takes place where all stakeholders are present and the leadership announces the start of the next phase.

Once a timed project plan and action plans that outline all activities have been approved, the project is ready to enter the implementation or executing phase. This stage is an actual executing of a series of processes and actions that where defined in the previous phase. This is the stage where committed resources work in teams to implement change that takes place and starts to fully or partially replace the previous way of conducting business. Although careful planning of actions and availability of resources play a crucial role in shaping the new environment, management commitment towards the objectives of the project remains the vital driver towards success. Continuous demonstration of support by the project sponsors must back the implementation effort.

Towards the completion of the project, the outcomes that have emerged from implementation would be evaluated to be certain of the project performance, and that a new environment has evolved in which the objectives have been fulfilled. There is no guarantee that all objectives will be satisfied at the same time; alternative actions must be considered whenever potential risk is identified.

In the aftermath of the project and once the final acceptance is signed off, project resources are released and may be rewarded relative to their effort. It is vital to celebrate success and make that renown. Furthermore, documenting the whole processes and history of the project and the learned lessons will maintain a solid history of the organization. As change must be campaigned for at a prior base, and must be fostered and may be guarded from some of those who are affected by it; not all people welcome change at all times.

\section{SWOT METHODOLOGY}

Change implies modifying or changing the way business is conducted, be it at the national, community, organization, unit or personal level. In reality, not all people applaud change, and even if they perceive it to be good, the degree of their perception is most likely to differ as their utility function differs. In a macroeconomic sense, change doesn't require that all participants, i.e. stakeholders of the project and the impacted environment must receive the same utility. This doesn't undermine the importance of the highest degree of "buy in". However, it is conceivable that some stakeholders may suffer from negative externalities as change takes place. Nevertheless, if it is to have a safe landing, certain conditions must be fulfilled prior and all the way through various phases of the project. They include: 
1. Strong commitment by the highest level of leaders and managers of the need for change, and acting as sponsors of the project.

2. Full understanding and admissibility of managers and leaders of their role through various stages of the project.

3. Availability of technical and functional staff to take or share the responsibility of the implementation of the project; in addition to their ability to maintain it after its completion.

4. Training staff to carry on their responsibilities with clear mandate and objectives.

5. Allocating reasonable time for the implementation.

6. Assure availability of data to be fed into the process.

7. Having well defined objectives that are realistic so that not to be over ambitious neither less than expected given the allocated resources.

8. Approved contingency plan(s).

9. Adopting a capable supervisory mechanism to monitor and assess progress.

The SWOT (Strengths, Weaknesses, Opportunities, and Threats) methodology is utilized at a prior stage before a project is initiated. It is usually the first step taken in strategic planning so that to provide enough information to formulate the objectives and action plans to implement. The SWOT analysis involves identifying factors that influence the organization and listing them in terms of their nature and importance. In general, these factors may be external or internal in nature, where external factors are those over which the organization management has little control; whereas internal factors are more within the control of management. Later, the external and internal factors will be defined in terms of whether they are considered to be source of strength, weakness, opportunity or threat. Factors that provide strength to the project should be strengthened further and be utilized towards success. On the other hand, sources of weakness have to be examined and handled so that to minimize their potential impact on success, and, if possible, may be transformed to be a source of strength. Opportunities may be there so that planners and management will have to optimize in the best possible way to enhance the success rate of the project. Actually, opportunities are the unrealized sources of strength. Threats represent a potential source of failure and collapse. Thus, management should allocate sufficient resources to minimize threats and their negative impact on the project. Consequently, actions plans will have to be developed in order to employ the outcome from the SWOT analysis towards the objectives of the project.

We shall utilize this approach to assess the degree of readiness of the GCC economies to introduce a common currency by the year 2010. However, instead of using this methodology as a determinant of the need for a single currency, it is employed to identify major sources of strength and risk to the project of the single currency among the GCC member states.

\section{GCC ENVIRONMENT FOR A SINGLE CURRENCY}

The economies of the GCC remain to be oil and gas dependent despite the increasing effort of economic diversification. Of the total value of the GCC's aggregate gross national product (GDP) which reached Euro 376 billion in 2004; oil and gas contributed about 35\%. One may argue that the actual impact of this sector on the whole economy is even greater once the interdependence between oil and gas and the other sectors of the economy is accounted for. For example, oil revenues finance over $80 \%$ of public spending. The economies of the GCC states remain essential to international economy given that about $42 \%$ of world oil reserves and $23 \%$ of proven gas reserves lay within their borders. With a population of about thirty five million people, average income per capita is about Euro 11,000 per year. Saudi Arabia is the largest in terms of size, population (about $70 \%$ of the total population) and GDP. Qatar and the UAE are the wealthiest, while Bahrain and Oman are lower-income countries. It should also be taken into consideration that Bahrain and Oman have limited oil reserve and forecasted to run out of oil within the next two decades. On the other hand, Kuwait, Saudi Arabia and the UAE will enjoy the windfall of oil for another one hundred years at least (European Central Bank, 2005). The European Union is the main source of imports of the GCC (about 30\%). With oil and gas being the major component of exports, East and South Asian region is the major destination of the GCC exports. Although the economies of the GCC are very open where the ratio of trade to GDP in any member state is least 60 percent, intra-trade in 2004 was only 5 percent of total exports, and only 30 percent if oil export was excluded (European Central Bank, 2005). 
Inflation has been relatively low in the region averaging about $5 \%$ over the last twenty years (it rose drastically in the last two years, about $10 \%$ ). The peg to the dollar; the limited use of monetary policy and the prominent role of public sector in the economy may explain the low inflation rate, where fiscal policy has been relatively stable over the last two decades, which was made possible by the substantial level of international reserves. Exchange rates among the GCC countries have been very stable due to the actual peg of five of their currencies to the dollar. While the Kuwaiti currency, the Dinar, was heavily pegged to the dollar. In addition, the similarity of the economic structures exposed them to similar shocks, where accumulation of foreign exchange reserves has always provided a shield against exchange rate volatility. Consequently, interest rate has experienced similar pattern across the GCC states. Ironically, these two elements have constrained the role of monetary policy while provoking greater reliance on fiscal policy. One may argue that, the stability and similarity of exchange rate, inflation rate and interest rate has facilitated de facto monetary policy coordination among member states of the GCC (Osman and Montasser, 2005).

Although they have similar economic structures, public debt in the member states of the GCC exhibited asymmetric behavior. This may be attributed to many factors including differentials in the size and components of public expenditure and revenue, differentials in fiscal policy tolerance (adjusting spending as revenues change) towards changes in revenues, and the size of previous surplus or deficit. Public debt as a ratio of GDP is diverged among these economies. For example, in 2004 Saudi Arabia recorded about 70 percent, whereas Bahrain and Qatar experienced a ratio of about 60 percent. On the other hand, countries like Oman and the UAE had a moderate debt ratio. With limited and weak sources of revenues to public budget, the situation of the budget remains highly viable to the international market for oil. Reducing public expenditure complemented with withdrawing from previously established foreign reserves has been a common adjustment mechanism whenever the price of oil experiences a drastic decline. An automatic stabilizing channel such as taxation system is very limited, thus narrowing tax base since there is no income or sales tax; some tariff, duties and fees constitute minor source of non-oil source of revenue.

As shown in Table (1), variations are wide in terms of per capita GDP and population; however, this stresses the need for mutual acceptance of the move towards monetary union; it has to be attractive enough and remains so. The UAE has the smallest share of oil in exports due to its strong reliance on re-exports to other GCC and other countries in the region.

Table (1): Main Economic and Vital Indicators, 2004

\begin{tabular}{|c|c|c|c|c|c|c|c|c|c|c|}
\hline$\stackrel{\Xi}{\Xi}$ & 畓令 & 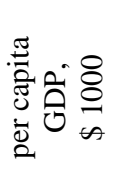 & 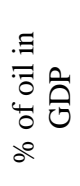 & 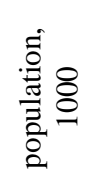 & 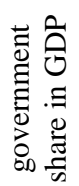 & 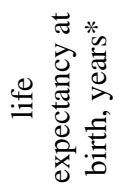 & 荃 & 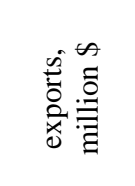 & 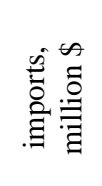 & 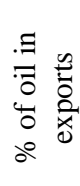 \\
\hline Bahrain & 10,000 & 14.14 & 25.2 & 707 & 17.7 & 74.3 & 0.846 & $7,518.60$ & 6,485 & 76.5 \\
\hline Kuwait & 49,400 & 18.00 & 49.4 & 2,754 & 20.5 & 77 & 0.844 & $26,267.20$ & 11,200 & 91.8 \\
\hline Oman & 24,824 & 10.40 & 42.4 & 2,395 & 17.7 & 74 & 0.781 & $13,381.30$ & 8,616 & 82.2 \\
\hline Qatar & 28,451 & 38.20 & 62.2 & 744 & 9.6 & 72.8 & 0.849 & $18,684.80$ & 5,914 & 86.6 \\
\hline $\begin{array}{l}\text { Saudi } \\
\text { Arabia }\end{array}$ & 248,799 & 10.70 & 41.4 & 23,305 & 16.2 & 72 & 0.772 & $120,000.50$ & 40,000 & 88.8 \\
\hline UAE & 103,134 & 23.90 & 32.8 & 4,320 & 8.5 & 78 & 0.849 & $82,750.40$ & 61,587 & 46.9 \\
\hline GCC & 464,608 & 13.57 & 41.3 & 34,225 & 14.7 & & & $268,602.70$ & 133,801 & 75.4 \\
\hline
\end{tabular}

Source: Gulf Statistical Profile, GOIC, 2005.

* Source: Human Development Report, UNDP, 2005.

Population includes nationals and expatriates. 


\section{TESTING WATERS: ARE THEY READY?}

Open countries are vulnerable to external and internal shocks. Looking at the GCC economies reveal the importance of these sources of shocks; however, being small, the six states have limited control over external shocks that have influence over their ultimate objective of launching a single currency by the year 2010. External factors include political impact of international events and politics. In this case, the GCC may be affected positively or negatively. Similarly, international economic conditions that determine demand and supply mirror on these small economies given their degree of openness. In addition, international and regional economic agreements and blocs are considered external to the GCC; however, the Gulf region can't be isolated.

While external factors remain directly influenced by international events, internal factors remain well within the scope of local policy makers. Looking at these factors from the perspective of the GCC as a single bloc that is moving towards a single currency, reveals a need for immediate actions on many fronts: political, economic and legal.

Table (2) sums up the most important internal factors that may constitute a source of strength, weakness, opportunity or threat towards January 2010. It is viewed here that satisfying these conditions of launching a single currency is not just fulfilling some macroeconomic conditions as commonly listed in the Optimum Currency Area literature (Mundel, 1961; McKinnon, 1963; Kenen, 1969; Ishiyama, 1975; Arab Planning Institute, 2002); rather, the SWOT analysis allows for micro issues to be noticed, investigated and resolved.

Table (2): SWOT Analysis of Internal Factors

S: strength; W: weakness; O: opportunity; T: threat

\begin{tabular}{|c|c|c|c|c|c|}
\hline \multirow[b]{2}{*}{ Factor } & \multicolumn{4}{|c|}{ Nature } & \multirow[b]{2}{*}{ Remark } \\
\hline & $\mathbf{S}$ & $\mathbf{W}$ & $\mathbf{O}$ & $\mathbf{T}$ & \\
\hline \multicolumn{6}{|l|}{ Political factors: } \\
\hline Political stability & $\mathrm{Y}$ & & $\mathrm{Y}$ & & no immediate threat to stability \\
\hline The way government deals with economic events & & $\mathrm{Y}$ & & $\mathrm{Y}$ & remains a national policy \\
\hline Government political policy towards foreign investment & $\mathrm{Y}$ & & & $\mathrm{Y}$ & remains a national policy \\
\hline Intervention of politicians in domestic businesses & & $\mathrm{Y}$ & & $\mathrm{Y}$ & politicians influence is wide \\
\hline Role of legislatives in economic policy & & $\mathrm{Y}$ & & $\mathrm{Y}$ & limited independence \\
\hline Role of independent political bodies & & $\mathrm{Y}$ & & $\mathrm{Y}$ & Very constrained or not existing \\
\hline \multicolumn{6}{|l|}{ Economic factors: } \\
\hline Economic maturity and economic structure & $\mathrm{Y}$ & & & Y & similar state of development and structure \\
\hline Role of private sector & $\mathrm{Y}$ & & $\mathrm{Y}$ & & increasing role across GCC \\
\hline Direction and magnitude of economic growth & & & & $\mathrm{Y}$ & $\begin{array}{l}\text { exhibit a co-movement, however could } \\
\text { diverge in the future }\end{array}$ \\
\hline Size of GDP and per capita & $\mathrm{Y}$ & & & $\mathrm{Y}$ & Vary across member countries \\
\hline Inflation rate & $\mathrm{Y}$ & & $\mathrm{Y}$ & & similar rates \\
\hline Accounting standards & & $\mathrm{Y}$ & & $\mathrm{Y}$ & heterogeneous systems and standards \\
\hline Wage policy & & $\mathrm{Y}$ & & $\mathrm{Y}$ & either lacking or ineffective \\
\hline Labor market structure & & $\mathrm{Y}$ & & $\mathrm{Y}$ & large expatriate labor \\
\hline Unemployment rate & $\mathrm{Y}$ & & & $\mathrm{Y}$ & Vary relatively, however, remains low \\
\hline Corporate tax & & $\mathrm{Y}$ & & $\mathrm{Y}$ & heterogeneous systems and rates \\
\hline Economic agreements with others & & $\mathrm{Y}$ & & $\mathrm{Y}$ & remains a national choice \\
\hline Interest rate & $\mathrm{Y}$ & & $\mathrm{Y}$ & & stable and similar \\
\hline Exchange rate & $\mathrm{Y}$ & & $\mathrm{Y}$ & & all currencies pegged to the dollar \\
\hline Monetary policy tools & & $\mathrm{Y}$ & & $\mathrm{Y}$ & different instruments and policies \\
\hline Fiscal policy tools & & $\mathrm{Y}$ & & $\mathrm{Y}$ & active policy across GCC, \\
\hline Size of public debt & $\mathrm{Y}$ & & & $\mathrm{Y}$ & varying debt to GDP \\
\hline Foreign exchange reserve & Y & & $\mathrm{Y}$ & & strong reserve position \\
\hline Size of domestic demand & $\mathrm{Y}$ & & $\mathrm{Y}$ & & $\begin{array}{l}\text { increasing demand given current income } \\
\text { growth, and given population growth }\end{array}$ \\
\hline Size of domestic supply & $\mathrm{Y}$ & & $\mathrm{Y}$ & & $\begin{array}{l}\text { increasing supply as the economy grows, the } \\
\text { magnitude differs }\end{array}$ \\
\hline
\end{tabular}


S: strength; W: weakness; O: opportunity; T: threat

\begin{tabular}{|c|c|c|c|c|c|}
\hline 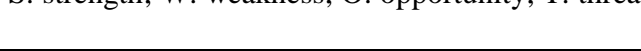 & \multicolumn{4}{|c|}{ Nature } & \multirow[b]{2}{*}{ Remark } \\
\hline Factor & $\mathbf{S}$ & $\mathbf{W}$ & $\mathbf{O}$ & $\mathbf{T}$ & \\
\hline Policy of subsidy to consumer and producer & $\mathrm{Y}$ & & $\mathrm{Y}$ & & $\begin{array}{l}\text { limited subsidy in most states, with some } \\
\text { exemptions for certain sectors }\end{array}$ \\
\hline Natural resources & $\mathrm{Y}$ & & & $\mathrm{Y}$ & High reserves though not evenly distributed \\
\hline Economic diversification & & & $\mathrm{Y}$ & $\mathrm{Y}$ & $\begin{array}{l}\text { increasing efforts towards diversification, } \\
\text { varying results }\end{array}$ \\
\hline Independence of central banks & Y & & & $\mathrm{Y}$ & $\begin{array}{l}\text { government control of all central banks with } \\
\text { no clear independency }\end{array}$ \\
\hline Foreign ownership of important economic factors & $\mathrm{Y}$ & & & $\mathrm{Y}$ & $\begin{array}{l}\text { diverged policies in initial ownership and its } \\
\text { size }\end{array}$ \\
\hline Openness of service sector & & $\mathrm{Y}$ & & $\mathrm{Y}$ & $\begin{array}{l}\text { different degree of openness even to other } \\
\text { GCC citizens }\end{array}$ \\
\hline Structure of imports and exports & $\mathrm{Y}$ & & $\mathrm{Y}$ & & $\begin{array}{l}\text { similar pattern allows for common external } \\
\text { shocks }\end{array}$ \\
\hline Relative freedom of some economic activities & & & $\mathrm{Y}$ & $\mathrm{Y}$ & this provides some degree of specialization \\
\hline Educational system & & $\mathrm{Y}$ & & $\mathrm{Y}$ & $\begin{array}{l}\text { lagged educational system compared to the } \\
\text { type of skills demanded }\end{array}$ \\
\hline External tariff & $\mathrm{Y}$ & & $\mathrm{Y}$ & & has been unified \\
\hline Intra-trade & & $\mathrm{Y}$ & & $\mathrm{Y}$ & remains low \\
\hline \multicolumn{6}{|l|}{ Legal factors: } \\
\hline Foreign ownership of real estate & & $\mathrm{Y}$ & & $\mathrm{Y}$ & heterogeneous legislations \\
\hline Foreign ownership of financial assets & & $\mathrm{Y}$ & & $\mathrm{Y}$ & $\begin{array}{l}\text { limited access of non-national in each country } \\
\text { to these assets }\end{array}$ \\
\hline Taxation systems and laws & & $\mathrm{Y}$ & & $\mathrm{Y}$ & diverged and weak base \\
\hline Commercial laws & & $\mathrm{Y}$ & & $\mathrm{Y}$ & $\begin{array}{l}\text { different laws governing companies and } \\
\text { commercial activities }\end{array}$ \\
\hline Banking legislations & & $\mathrm{Y}$ & & $\mathrm{Y}$ & $\begin{array}{l}\text { each country has its own laws governing } \\
\text { banks and their operations }\end{array}$ \\
\hline Financial market laws & & $\mathrm{Y}$ & & $\mathrm{Y}$ & $\begin{array}{l}\text { different degree of openness due to different } \\
\text { laws }\end{array}$ \\
\hline Environmental legislations & & $\mathrm{Y}$ & & $\mathrm{Y}$ & $\begin{array}{l}\text { different policies and inefficient independent } \\
\text { laws enforcement entity }\end{array}$ \\
\hline Health ,labor and safety legislations & & $\mathrm{Y}$ & & Y & the member states have diverged legislations \\
\hline Patent and trade marks laws & $\mathrm{Y}$ & & & $\mathrm{Y}$ & $\begin{array}{l}\text { the member states have adopted a common } \\
\text { measure }\end{array}$ \\
\hline Legislations governing foreign investment & & & $\mathrm{Y}$ & $\mathrm{Y}$ & each country has its own legislations and laws \\
\hline Consumer protection laws & $\mathrm{Y}$ & & & $\mathrm{Y}$ & diverged laws \\
\hline Minimum wage laws & & $\mathrm{Y}$ & & $\mathrm{Y}$ & $\begin{array}{l}\text { either non-existing or ineffective in all } \\
\text { countries }\end{array}$ \\
\hline Tax exemption laws & & $\mathrm{Y}$ & & $\mathrm{Y}$ & divergence in these laws \\
\hline Legislations defining national product & $\mathrm{Y}$ & & $\mathrm{Y}$ & & $\begin{array}{l}\text { the member states have adopted a common } \\
\text { measure }\end{array}$ \\
\hline Immigration and residence laws & & $\mathrm{Y}$ & & $\mathrm{Y}$ & $\begin{array}{l}\text { each country has its own laws and rules } \\
\text { governing immigration and residence permit }\end{array}$ \\
\hline Nationalizing jobs & & $\mathrm{Y}$ & & $\mathrm{Y}$ & $\begin{array}{l}\text { all countries adopt a policy of imposing quota } \\
\text { in public jobs for nationals }\end{array}$ \\
\hline Laws governing entry in service sector & & $\mathrm{Y}$ & & $\mathrm{Y}$ & different laws and degree of freedom \\
\hline
\end{tabular}


S: strength; W: weakness; O: opportunity; T: threat

\begin{tabular}{|c|c|c|c|c|c|}
\hline 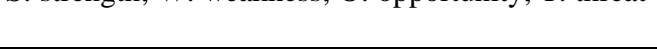 & \multicolumn{4}{|c|}{ Nature } & \multirow[b]{2}{*}{ Remark } \\
\hline Factor & $\mathbf{S}$ & $\mathbf{W}$ & $\mathbf{O}$ & $\mathbf{T}$ & \\
\hline Other factors: & & & & & \\
\hline Availability and transparency of data & & Y & & Y & $\begin{array}{l}\text { limited data is public and suffer from } \\
\text { inconsistency and long lags }\end{array}$ \\
\hline Super-national bank & & $\mathrm{Y}$ & & $\mathrm{Y}$ & $\begin{array}{l}\text { need to step up the process though a currency } \\
\text { board was formed in } 2006\end{array}$ \\
\hline Time left to 2010 & & $\mathrm{Y}$ & & $\mathrm{Y}$ & $\begin{array}{l}\text { time is very short when policy change and } \\
\text { setting up institutions are considered essential }\end{array}$ \\
\hline Convergence criteria & & $\mathrm{Y}$ & & $\mathrm{Y}$ & $\begin{array}{l}\text { Not clear how all economies will converge } \\
\text { since they are already members of the single } \\
\text { currency area. Not yet agreed on the details }\end{array}$ \\
\hline Current economic conditions & & & $\mathrm{Y}$ & $\mathrm{Y}$ & $\begin{array}{l}\text { current levels of oil income allows for } \\
\text { financing costly decisions }\end{array}$ \\
\hline Past intra-regional cooperation & & $\mathrm{Y}$ & & $\mathrm{Y}$ & $\begin{array}{l}\text { many previous cooperation experiences were } \\
\text { ineffective }\end{array}$ \\
\hline Super-national political institutions & & $\mathrm{Y}$ & & $\mathrm{Y}$ & $\begin{array}{l}\text { no super-national political institutions, making } \\
\text { policy enforcement difficult }\end{array}$ \\
\hline Super-national economic institutions & & $\mathrm{Y}$ & & $\mathrm{Y}$ & $\begin{array}{l}\text { no super-national economic institutions, } \\
\text { making policy enforcement difficult }\end{array}$ \\
\hline Super-national legal institutions & & $\mathrm{Y}$ & & $\mathrm{Y}$ & $\begin{array}{l}\text { no super-national legal institutions, making } \\
\text { policy enforcement difficult }\end{array}$ \\
\hline Public awareness of the single currency & & $\mathrm{Y}$ & & $\mathrm{Y}$ & public awareness is very low \\
\hline Language, religion, traditions, political system & $\mathrm{Y}$ & & $\mathrm{Y}$ & & same in all member states \\
\hline
\end{tabular}

As a project, while on the one hand the single currency requires immediate policies to boost the factors that constitute a source of strength, it, on the other hand, calls for urgent policies and action plans designed to eliminate sources of weakness. Capitalizing on factors of strength should be looked upon from the perspective of the GCC as a region rather than an individual member state. Evidently, the region faces some challenges that must be overcome if a successful single currency were to be issued in 2010. Institutional arrangements should be given the priority. Institutions such as the super national central bank, legislative and governing bodies, and implementation entities (teams), will have to be functioning soon. Many factors require urgent attention because they tend to have implicative effect on other sectors due to their nature of interdependence. This is noticeable in commercial laws, banking and financial markets legislations and regulations, taxation, and separation of political interest from economic policy. Coordination of laws, regulations and rules aims at unifying the systems so that to create an environment where all participants abide and operate according to the same rules. Any discrepancy is sufficient of disrupting and disarraying efforts towards 2010; countries may lose interest if they feel that not all members have the same chance to benefit from the monetary union.

Politically, three factors pose a serious threat to the drive towards launching a single currency among the GCC states. First, politicians hold direct interest and influence on domestic business. This poses a threat because it views a national interest above that of the bloc and thus, may lead to divergence on adopted policies affecting domestic business environment in each country. Second, legislators have limited independent freedom to take impartial decisions. Once more, this is capable of diverting common policies at the GCC level. Third, the lack of independent political bodies at the state and the Council levels may slow decision-making processes towards 2010. On the other hand, the emerging decision by all member states to open up their economies to foreign investment, if can be pooled into a similar policy, is considered a point of strength; however, may become a threat if it is left to each member state.

Table (2) lists a number of economic factors derived from the SWOT analysis. They include points of strength, weakness, opportunity and threat. On the strength side, the GCC states have similar low inflation rate; limited role of monetary policy, similar interest rate, fixed bilateral exchange rate, high level of international reserves, similar import and export structures, and common external tariff. Economically, these sources of strengths 
contribute to the march towards the single currency, and minimize the need to design alternative economic policy. There remain some significant factors of weakness, they include: a growing expatriate labor market posing a challenge to the increasing number of unemployed indigenous labor force (unemployment data is lacking in the GCC); each country endorsing separate economic agreement with other countries; strong reliance on fiscal policy which, if not closely watched could favor some members on others; and the relatively closed service sector.

Almost all legal factors imply a degree of concern to the single currency project. Among them is the lack of common banking and financial market legislations. If each state is left to preach its own laws and regulations, the common objective will be missed. This set of factors requires urgent attention since it takes time to prepare, draft and finalize legislations; businesses need time to comply with the new laws.

In addition to the sets of political, economical and legal factors, there are other crucial factors; they include setting up super-national institutions; the business owners of the GCC ultimate objective of monetary or even economic union. The lack or delay in initiating and empowering institutions such as the central bank of the GCC, the legal entity such the supreme court of the GCC, the political effective body such as the council of the GCC, and similar institutions, contain a serious source of failure towards the year 2010.

As of May 2006, it has been recommended by working committees to define convergence criterion to include: inflation rate, interest rate, international reserves, the ratio of deficit to GDP, and the ratio of public debt to GDP; however, a final decision remains on the agenda of the heads of the states' meeting in December 2006. Nonetheless, there is acute lack of public information regarding policies designed to compact factors that constitute a source of weakness to this project. Regardless of what may be achieved economically, political commitment remains the most important type of ownership of the single currency agreement. At the highest governing entity, leaders must demonstrate a firm commitment to 2010 and disseminate that in all occasions. Some national sovereignty must be given up to new central bodies, where the region's interest is at the top of its list. These bodies must be born big and strong so that to be effective and reliable. It remains true that technocrats should carry on the task of implementing the project and maintaining it afterward, however, without strong commitment of politicians, disbelievers may grow in numbers.

Change management is a mechanism that focuses on preaching a new culture, new belief, and new way of doing things. Although it is relatively simple to introduce new laws, rules and equipment; change is people dependent; it is for the people and by the people. Any project has objectives to fulfill and requires planning and implementation. Participants must acquire full knowledge to understand why they need the proposed change, what will the alternative offer them, what is expected of them, and what will it take to adopt the new environment. Resistance must be overcome by persuasion to the extreme, and management should always admit that new cultures are not always welcome.

In the aftermath of the SWOT analysis in the case of the single currency project, action plans must be prepared where they all focus on the strategic goal of paving the way for a single currency to be launched by January 2010. This is accomplished through developing sub-strategies for similar factors that require specific actions. For example, political factors will have a strategy developed with a set of goals aiming at creating the proper political environment towards the objective. The same would be done for other factors. Action plans would be derived from these strategies where activities will be timed, responsibilities will be defined, and a follow up mechanism will be endorsed. Events that aren't scheduled tend to be lost and lead to inefficient outcomes. Thus, good project management of the single currency project must result in specified actions and responsibilities and follow up, where corrective actions may be necessary so that to overcome potential sources of risk.

One may argue that other Arab countries can look upon a successful monetary union amongst the GCC states as a model. Moreover, once it is achieved and embeds a system of admitting new members, it may grow in size like the European Union. Thus, setting up the right rules and regulation as well as the super-national bodies, will provide a solid base to attract others in line with pre-determined conditions. It will also eliminate divergence in economic policies signaling a unified economic area to the rest of the world. Equally, if efforts towards a single currency fail, an opposite signal will be disseminated. 


\section{CONCLUSION}

The member states of the Gulf Cooperation Council (GCC) have agreed to issue a single currency by 2010; an ambitious step given the modest achievements since the establishment of the Council in 1981. SWOT analysis of factors influencing the environment towards the targeted date, revealed a number of factors that constitute a source of strength; however, a significant number of weaknesses demand immediate actions to be overcome. To the governments, businesses and people of these small economies, the endorsement of the single currency agreement is about launching a new culture. To be successful, change must be managed from the point of inception and for a long time. Unlike the European experience of the Euro, public awareness of what it takes to arrive at 2010 remains shallow. The project has no clear ownership; that is why super-national institutions must be established urgently and empowered even if a gradual pace is adopted as an approach to this.

\section{REFERENCES}

1. Fasano, Ugo, et. al (2003). Monetary Union Among Member Countries of the Gulf Cooperation Council. IMF, Occasional Paper, no. 223.

2. $\quad$ Human Development Report (2005). UNDP.

3. Ishiyama, Yoshihide (1975). The Theory of Optimum Currency Areas: A Survey. IMF Staff Papers, vol. 22, no. 2, p. 344-383.

4. Kenen, P. (1969). The Theory of Optimum Currency Areas: An Eclectic View. In: R. A. Mundel and A. K. Swoboda, Monetary Problems of the International Economy, Chicago: University of Chicago, p. 41-60.

5. Laabas, Belkacem, and Imed Limam (2002). Are GCC Countries Ready for Currency Union? Arab Planning Institute.

6. McKinnon, Ronald (1963). Optimum Currency Areas. American Economic Review, vol. 53, p. 717-725.

7. Mundell, R. A. (1961). A Theory of Optimum Currency Areas. American Economic Review, vol. 51, p. 657-665.

8. Osman, Osman, and Essam Montasser (2005). GCC and the Arab Economy: Growth, Reform, and Regionalization. Economic Research Forum, Working Paper.

9. Sturm, Michael, and Nikolaus Siegfried (2005). Regional Monetary Integration in the Member States of the Gulf Cooperation Council. European Central Bank, Occasional Paper Series, no. 31.

10. Sturm, Michael (2006). European Monetary Union: Potential Lessons for a Common Currency in the GCC. Conference Proceedings: The Unified Currency for GCC Countries, Dubai. 